\title{
Effect of aging on the leachate characteristics from municipal solid waste landfill
}

\author{
B.P. Naveen ${ }^{\text {i), P.V. Sivapullaiah }}{ }^{\text {ii) }}$ and T. G. Sitharam ${ }^{\text {iii) }}$
}

\begin{abstract}
i) Ph.D Student, Department of Civil Engineering, Indian Institute of Science, Bangalore 560012, India.
ii) Professor, Department of Civil Engineering, Indian Institute of Science, Bangalore 560012, India.

iii) Professor, Department of Civil Engineering, Indian Institute of Science, Bangalore 560012, India.
\end{abstract}

\begin{abstract}
Leachate emanating from solid waste deposited in landfill possess dissolved or an entrained environmentally harmful substances. They consist of soluble organic and inorganic compounds as well as suspended particles. These leachates also have a distinguishing characteristic in that they are highly variable and contain significantly elevated concentrations of undesirable material derived from the waste. Depending on whether leachate flow increases (during rainy season) and decreases (during dry/summer season) can change the composition. The concentration of waste change dramatically changes over the life of the landfill due to chemical degradation and biological decay of organic matter present. Consequently, the physical characteristics also vary considerably depending on the age of the waste. This paper brings out the effect of aging on the leachate characteristics from a municipal solid waste located at the Terra Firma Biotechnologies Ltd situated at Gundlahalli village in Doddaballapur taluk, near Bangalore. For the sake of comparison the leachates from two different parts of the site one from the location where old waste was dumped and another from the location where the waste was dumped relatively recently during the same period. Thus the two leachate samples from the same site representing different stages degradation of waste were collected to represent leachate from old waste and another from relatively fresh waste. The samples were analyzed for various physicochemical parameters to estimate its pollution potential. The results showed that most of the parameters examined in the leachate samples such as colour, conductivity, hardness, BOD, COD, TOC were found higher in the fresh leachate than aged leachate. In addition, low BOD/COD ratio of $<0.1$ in aged leachate and BOD/COD ratio of 0.33 in fresh leachate are observed. This shows that the major portion is organic matter which is not quickly biodegradable in the leachate from Terra Firma Biotechnology. The compost site is non-engineered solid waste landfill, which has neither bottom liner system nor any leachate collection and treatment system. Hence, leachate may percolate through subsoil causing pollution to ground water and surface water resources. Further the properties of soil below can change due to changing composition of the pore fluid.
\end{abstract}

Keywords: Aging, BOD, COD, Leachate, Municipal Solid Waste.

\section{INTRODUCTION}

Leachate is a contaminated liquid that drains through the bottom of the solid waste disposal facilities such as landfills. Its composition varies widely depending on the composition of waste as well as the age of waste. It contains number of dissolved and suspended materials. After municipal solid waste landfill site is closed, landfill will continue to produce contaminated leachate and this process can last for 30-50 years which can have significant environmental impact when released untreated into the environment(Peter et al., 2002). Quality of leachate is site-specific and even at a single landfill site the quality of leachate is strongly variable. Variability caused by many factors such as rainfall regime, geology, landfill age, composition of solid waste, physico-chemical conditions at the landfill (Zgajnar et al., 2009).

Within the land fill waste mass, biodegradable waste includes food waste, green waste and certain wastes arising from commercial and industrial sources. This kind of waste will easily decompose within the first few months of disposal. Non biodegradable waste like paper, wood and plastics also yield organic compounds to leachate, but only in small percentage over long periods of time. The majority of inorganic compounds are readily soluble and the ions released usually appear within a short time. Heavy metals contained in the solid waste are usually released slowly into the leachate and the process may take up to several years. Moreover, there is a complex interplay between leaching of ionic species and the maturity of the solid waste landfill site. This affects the compositional characteristics of the leachate (Renou et al., 2005).

As landfill passes through different phases of its life cycle, the leachate composition also varies widely 
through the successive aerobic, acetogenic, methanogenic and stabilization stages. The degradation process of the waste in a landfill passes through different phases. The first phase which is normally short is characterized by the aerobic degradation of organic matter, $\mathrm{CO} 2$ is produced and the temperature of waste can increase up to $80^{\circ} \mathrm{C}$, this can affect the later stage of leachate production. In this phase, leachate contributes moisture during compaction as well as from precipitation through the buried waste (Kjeldsen et al., 2002). The amount of leachate leaving the landfill is limited due to the water holding by the waste, until the leachates reaches the collection system and is drained to the collection basin(Armstrong and Rowe,1999). This stage usually lasts only a few weeks and consequential phase appears when the oxygen is depleted, the degradation continues anaerobically. The anaerobic degradation process consists of two major fermentation phases, the acidogenic phase generating young, biodegradable leachate and the methanogenic phase, generating old, stabilised leachate (Bhala et al., 2012).

Young leachate from the early acidogenic phase contains large amounts of readily biodegradable organic matter. The complex organic compounds are fermented anaerobically, yielding mainly soluble organic acids such as free volatile fatty acids (VFAs), amino acids, other low molecular weight compounds and gases like $\mathrm{H}_{2}$ and $\mathrm{CO}_{2}$ (Harmsen, 1983). The concentration of VFAs can be quite significant, representing $95 \%$ of the TOC, leading to low $\mathrm{pH}$ (less than 5). BOD5/COD will have high ratio values of 0.5-0.7 indicate large amounts of biodegradable organic matter (Granet et al., 1986). COD values are 3,000-60,000 mg/l (Aisien et al., 2010). During this phase the metals are more soluble because of lower $\mathrm{pH}$ and the bonding with the VFAs, leading to relative high concentrations of Fe, Mn, Ni and Zn (Harmsen, 1983).

Old leachate will be in the methanogenic phase with lower concentration of VFAs (Chain and Dewalle, 1976). This is due to their conversion into methane and carbon dioxide (CO2) as gaseous end products during this second fermentation period. VFAs and other readily biodegradable organic compounds in the leachate decreases, the organic matter in the leachate becomes dominated by refractory compounds, such as humic like compounds and fulvic acid like substances (Chian and Dewalle,1976). Thus BOD5/COD will have low ratio values, most often close to 0.1 , is a characteristic value for stabilised leachates. The dark colour in leachate is mainly due to humic substance. The decrease of VFAs results in an increase in $\mathrm{pH}$. A characteristic $\mathrm{pH}$ value for stabilised leachate is close to 8 (Granet et al., 1986). The concentration of metal ions is in general low due to the decreasing solubility of many metal ions with increasing $\mathrm{pH}$. In case of lead, it forms very stable complexes with the humic acids (Harmsen, 1983). Due to the effect of the shifting $\mathrm{pH}$ on metal-ions, reduction of sulphate to sulphide during methanogenic phase, this increases the precipitation of metals ions.

Generally, leachate strength get reduces with time due to biological breakdown of organic compounds and precipitation of soluble elements like heavy metals. With increasing age of leachate production, the organic compounds decrease more rapidly than the inorganic compounds. Hence, the ratio of total volatile solids to total fixed solids decreases with the age of the landfill (Robinson and Gronow, 1993)

The aim of our study is to bring out the effect of aging on the leachate characteristics from a municipal solid waste of Terra Firma Biotechnologies Ltd situated at Gundlahalli village in Doddaballapur taluk, near Bangalore. Two leachate samples were collected at different locations from the same site representing different stages of degradation of waste. Further the leachate contamination potential has been assessed based on the concept of leachate pollution index (LPI).

\section{SITE DESCRIPTION}

Terra Firma Biotechnologies Ltd(TFBL) is situated at Gundlahalli village, $18 \mathrm{~km}$ from Doddaballapur taluk of Karnataka state,India. TFBL receives about 1,000 tons of MSW daily from BBMP while remaining 400 tons of MSW is collected from hotels, IT parks..etc. The MSW collected is treated through composting, biomethanation and landfill facility. The first leachate (sample-1) originated from the old part of the landfill as show in fig 1.

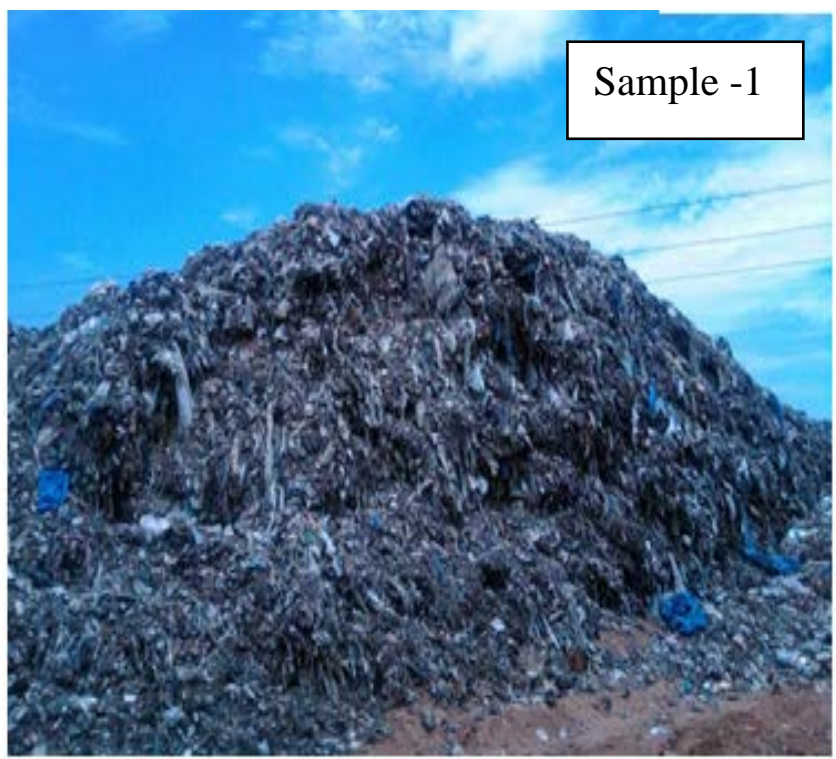

Fig. 1 Leachate location from the Old part of the Landfill 
The second leachate (sample-2) was sampled at the same landfill but it is active part of the landfill as show in fig 2.

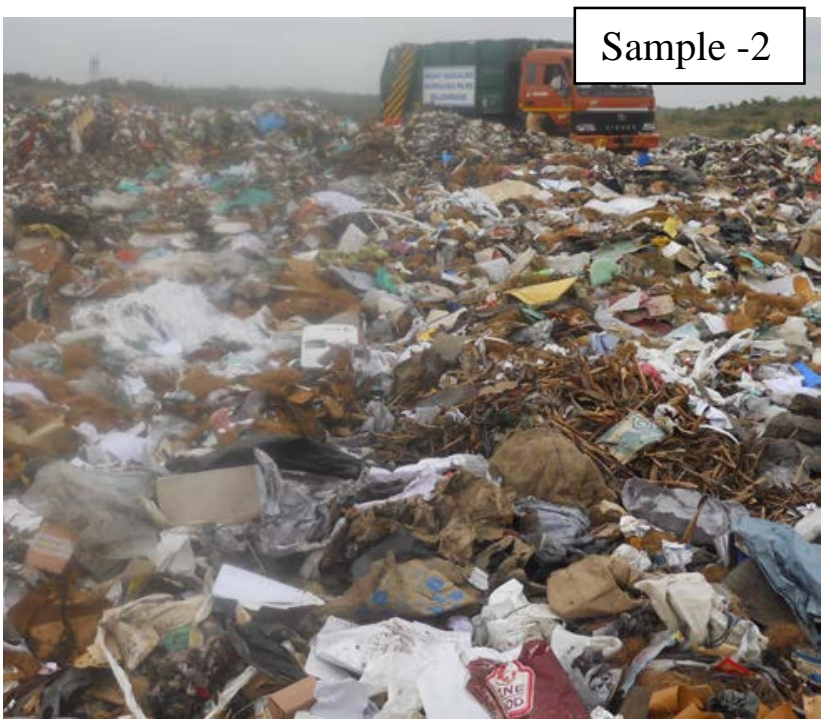

Fig. 2. Leachate location from the fresh dump site

\section{SAMPLING AND ANALYSES}

A municipal solid waste leachate sample was collected in the month of April from the Terra Firma Biotechnologies Ltd in Bangalore. Glass bottles were used to collect leachate samples for chemical analyses, whereas, samples preserved for BOD and COD tests were collected in polyethylene bottles covered with aluminium foils. A few drops of concentrated nitric acid were added to the leachate sample collected for heavy metals analysis to preserve the samples. The samples were then transported in cooler boxes at temperature below $5^{\circ} \mathrm{C}$, and transported immediately to the laboratory. Sample of leachate were stored in refrigerator at $4^{\circ} \mathrm{C}$ before proceeding for the analysis. The analysis is carried out according to standard methods for examination of water and wastewater unless otherwise stated (APHA, 1998).

\subsection{Determination of Physico-chemical parameters}

Table 1. Method of determination of Physico-chemica parameters

\begin{tabular}{ll}
\hline Parameters & Method of determiantion \\
\hline $\mathrm{pH}$ & $\mathrm{pH}$ meter \\
\hline $\begin{array}{l}\text { Conductivity, } \\
\mu \mathrm{S} / \mathrm{cm}\end{array}$ & Conductivity meter \\
\hline $\mathrm{TDS}, \mathrm{mg} / \mathrm{l}$ & TDS meter \\
\hline $\mathrm{COD}, \mathrm{mg} / \mathrm{l}$ & Open reflux method \\
\hline $\mathrm{BOD}_{3}, \mathrm{mg} / \mathrm{l}$ & Winkler's method \\
\hline Sulphate, $\mathrm{mg} / \mathrm{l}$ & Titration \\
\hline Chloride, $\mathrm{mg} / \mathrm{l}$ & Titration \\
\hline Calcium, $\mathrm{mg} / \mathrm{l}$ & EDT titration \\
\hline Alkalinity, mg/l & EDT titration \\
\hline
\end{tabular}

\begin{tabular}{ll}
\hline Sodium, $\mathrm{mg} / \mathrm{l}$ & flame photometer method \\
\hline Potassium, $\mathrm{mg} / \mathrm{l}$ & flame photometer method \\
\hline Nitrate, $\mathrm{mg} / \mathrm{l}$ & Spectrophotometer method \\
\hline Heavy metal & Absorption Spectrophotometer \\
\hline
\end{tabular}

\section{RESULTS AND DISCUSSION}

The physico-chemical properties of both leachates are presented in Table 2.

Table 2. Leachate characteristic of TFBL

\begin{tabular}{lll}
\hline Details & Sample-1 & Sample-2 \\
\hline pH & 7.38 & 5.7 \\
\hline Colour & Brownish & Dark Black \\
\hline Odour & Very High & Medium \\
\hline Temperature, ${ }^{\circ} \mathrm{C}$ & 29 & 29 \\
\hline Conductivity, $\mu \mathrm{S} / \mathrm{cm}$ & 2750 & 1050 \\
\hline Turbidity $(\mathrm{NTU})$ & 470 & 80 \\
\hline TDS, $\mathrm{mg} / \mathrm{l}$ & 1375 & 310 \\
\hline COD, mg/l & 498 & 4960 \\
\hline BOD, $\mathrm{mg} / \mathrm{l}$ & 40 & 1680 \\
\hline Sulphate, mg/l & 42 & 30 \\
\hline Chloride, mg/l & 960 & 2300 \\
\hline Calcium, mg/l & 159 & 680 \\
\hline Hardness, mg/l & 26000 & 30000 \\
\hline Alkalinity, mg/l & $-\mathrm{Nil}-$ & 2500 \\
\hline Iron, $\mathrm{mg} / \mathrm{l}$ & 5.28 & 6.61 \\
\hline Copper, mg/l & 0.001 & 0.223 \\
\hline Silver, $\mathrm{mg} / \mathrm{l}$ & 0.785 & 0.192 \\
\hline Chromium, mg/l & BDL & BDL \\
\hline Cadmium, mg/l & 0.026 & 0.015 \\
\hline Lead, mg/l & 0.252 & 0.145 \\
\hline Zinc, mg/l & 48 & 0.2 \\
\hline Nickel, mg/l & 0.074 & BDL \\
\hline Sodium, mg/l & 260 & 508 \\
\hline Potassium , mg/l & 200 & 508 \\
\hline Nitrate,mg/l & 82.73 & 8.91 \\
\hline & & \\
\hline
\end{tabular}

The Sample-1 leachate originating from the old landfill had typical properties of leachate from landfill in the methonogenic phase (Kjeldsen et al., 2002). High $\mathrm{pH}$, low concentration of organic matter and typically very low $\mathrm{BOD}_{5} / \mathrm{COD}$ ratio $(<0.1)$, indicating low biodegrability potential.

On the other hand, leachate from the active part of the landfill (sample-2) was significantly more polluted, it contained high concentrations of chlorides, sulphate, calcium and its $\mathrm{pH}$ was lower (5.7) indicate that the landfill is at the end of the acidic anaerobic phase (waste buried in the landfill is about 4 years) and it will proceed to another phase i.e. methanoenic.

The sample -2 leachate is a strongly odoured black coloured liquid when it comes from a landfill site. The 
smell is acidic and offensive because of sulfur, hydrogen and nitrogen rich organic species such as an organosulfur compound As it becomes oxygenated it tends to turn brown because of the presence of Iron salts in solution and in suspension. It also quickly develops a bacterial flora often comprising substantial growths of Sphaerotilus.

Concentrations of metals were low in both leachates samples except for $\mathrm{Fe}$ and $\mathrm{Zn}$. Generally heavy metals appear in the municipal solid waste from Batteries, consumer electronics, ceramics, light bulbs, house dust and paint chips, lead foils such as wine bottle closures, used motor oils, plastics, and some inks and glass. Concentration of heavy metals in a landfill is generally higher at earlier stages because of higher metal solubility as a result of low $\mathrm{pH}$ caused by production of organic acids. It is now recognized that most trace elements are readily fixed and accumulate in soils, and because this process is largely irreversible, repeated applications of amounts in excess of plant needs eventually contaminate a soil and may either render it non-productive or the product unusable. Although plants do take up the trace elements, the uptake is normally so small that this alone cannot be expected to reduce appreciably the trace element. It is interesting to note that the zinc levels are very high in leachate from old waste compared to leachate from fresh waste. However the concentrations of iron is about the same in the both the leachate samples.

\subsection{Indications from BOD and COD values}

The BOD/COD ratio can used to indicate the age of the waste fill. Relatively BOD levels decrease with age faster than COD due to rapid disintegration of bio degradable waste. Thus generally the ratio of BOD/COD will decrease with age and can be used to indicate the age of the waste.. Any waste water, having its $\mathrm{BOD}_{5} / \mathrm{COD}$ ratio more than 0.63 can be considered to be quite controlled to biological treatment.

Table 3. Age of waste based on BOD \& COD values of leachate (Hui, 2005).

\begin{tabular}{lll}
\hline BOD5/COD & Age of fill & COD \\
\hline$\geq 0.5$ & Young $(<5 \mathrm{yr})$. & $>10,000$ \\
\hline $0.1-0.5$ & Medium(5yr $-10 \mathrm{yr})$ & $500-10,000$ \\
\hline$<0.1$ & Old $(>10 \mathrm{yr})$ & $<500$ \\
\hline
\end{tabular}

From table 3, it shows that $\mathrm{BOD}_{5}$ was 1290 $\mathrm{mg} / \mathrm{l}$ and the value of COD was $13400 \mathrm{mg} / \mathrm{l}$. The ratio of $\mathrm{BOD}_{5} / \mathrm{COD}$ is 0.09 for sample- 1 leachate. The value of $\mathrm{BOD}_{5} / \mathrm{COD}$ can characterize the age of the landfill according to the leachate constituents (Table 3). The value of $\mathrm{COD}$ and $\mathrm{BOD}_{5} / \mathrm{COD}$ from Table 3 shows that the leachate (sample-1) in this study was collected from the landfill with a age of more than 10 years and (sample-2) leachate found to be in medium age between 5 and 10 years.

\section{LEACHATE POLLUTION INDEX CONCEPT}

LPI provides an efficient method for evaluating the leachate contamination potential. The leachate pollution index (LPI) and it is formulated based on the Delphi technique. The LPI is a quantitative tool by which the leachate pollution data of the landfill sites can be reported uniformly. LPI formulation process involves selecting variables, deriving weights for the selected pollutant variables, formulating their sub indices curves, and finally aggregating the pollutant variables to arrive at the LPI (Kumar and Alappat, 2003).

LPI process involves: Selection of pollutant variables, Pollutant weights are assigned, formulating their sub indices curves and aggregating the pollutant variables to arrive at the LPI.

The LPI is calculated using the following equations:

$$
L P I=\sum_{\mathrm{i}=1}^{\mathrm{n}} \mathrm{WiPi}
$$

Where LPI= the weighted additive LPI, Wi= the weight for the ith pollutant variable, $\mathrm{Pi}=$ the sub index score of the ith leachate pollutant variable, $n=$ number of leachate pollutant variables used in calculating LPI.

However, when the data for all the leachate pollutant variables included in LPI are not available, the LPI can be calculated using the concentration of the available leachate pollutants. In that case, the LPI can be calculated by the equation:

$$
L P I=\frac{\sum_{i=1}^{m} W_{i P i}}{\sum_{i=1}^{m} W i}
$$

Where $\mathrm{m}$ is the number of leachate pollutant parameters for which data are available, but in that case, $\mathrm{m}<18$ and $\Sigma \mathrm{W}<1$ contamination from the pollutant to the overall leachate pollution.

LPI values were calculated for leachate sample of Terra Firma site. Tables 4 show the calculations for LPI values of leachate samples in Terra Firma site. 
Table 4. LPI for the landfill leachate (sample-1)

\begin{tabular}{lllll}
\hline $\begin{array}{c}\text { Pollutant, } \\
\mathrm{mg} / \mathrm{l}\end{array}$ & $\begin{array}{c}\text { Sample } \\
1\end{array}$ & $\mathrm{~W}_{\mathrm{i}}$ & $\mathrm{P}_{\mathrm{i}}$ & $\left(\mathrm{P}_{\mathrm{i}} \mathrm{W}_{\mathrm{i}}\right)$ \\
\hline $\mathrm{pH}$ & 7.38 & 0.055 & 5 & 0.275 \\
\hline $\mathrm{TDS}$ & 1375 & 0.050 & 8 & 0.40 \\
\hline $\mathrm{BOD}_{5}$ & 40 & 0.061 & 55 & 3.36 \\
\hline $\mathrm{COD}$ & 498 & 0.062 & 80 & 4.96 \\
\hline $\mathrm{TKN}$ & 831 & 0.053 & 95 & 5.035 \\
\hline $\mathrm{AN}$ & 1 & 0.051 & 100 & 5.10 \\
\hline Iron & 5.28 & 0.044 & 5 & 0.22 \\
\hline Copper & 0.001 & 0.050 & 5 & 0.25 \\
\hline Nickel & 0.074 & 0.052 & 5 & 0.26 \\
\hline Zinc & 48 & 0.056 & 5 & 0.28 \\
\hline Lead & 0.252 & 0.063 & 5 & 0.31 \\
\hline Chromium & 0.011 & 0.064 & 10 & 0.64 \\
\hline Chlorides & 960 & 0.048 & 5.3 & 0.2544 \\
\hline Final LPI value & $=13.22$ & & \\
\hline
\end{tabular}

Table 5. LPI for the landfill leachate (sample-2)

\begin{tabular}{llllc}
\hline $\begin{array}{c}\text { Pollutant, } \\
\mathrm{mg} / \mathrm{l}\end{array}$ & $\begin{array}{c}\text { Sample } \\
2\end{array}$ & $\mathrm{~W}_{\mathrm{i}}$ & $\mathrm{P}_{\mathrm{i}}$ & $\left(\mathrm{P}_{\mathrm{i}} \mathrm{W}_{\mathrm{i}}\right)$ \\
\hline $\mathrm{pH}$ & 5.7 & 0.055 & 5 & 0.275 \\
\hline $\mathrm{TDS}$ & 310 & 0.050 & 8 & 0.40 \\
\hline $\mathrm{BOD}_{5}$ & 1680 & 0.061 & 55 & 3.36 \\
\hline $\mathrm{COD}$ & 4960 & 0.062 & 80 & 4.96 \\
\hline $\mathrm{TKN}$ & 485 & 0.053 & 95 & 5.035 \\
\hline $\mathrm{AN}$ & 350 & 0.051 & 100 & 5.10 \\
\hline Iron & 6.61 & 0.044 & 5 & 0.22 \\
\hline Copper & 0.223 & 0.050 & 5 & 0.25 \\
\hline Nickel & 0.001 & 0.052 & 5 & 0.26 \\
\hline Zinc & 0.2 & 0.056 & 5 & 0.28 \\
\hline Lead & 0.145 & 0.063 & 5 & 0.31 \\
\hline Chromium & 0.001 & 0.064 & 10 & 0.64 \\
\hline Chlorides & 2300 & 0.048 & 5.3 & 0.2544 \\
\hline Final LPI value $=16.11$ & & \\
\hline
\end{tabular}

The results indicate that the leachate sample has high LPI value and therefore, has relatively more contamination potential. Terra Firma leachate sample can therefore pose threat to the environment and human health and hence, measures and continuous monitoring must be ensured. This threat potential does not seem to be reducing even with increase of the leachate.

It is interesting to note that the LPI of both the leachates is not much different. While pollution threat from Leachate 1 (from old waste) is less from BOD and COD, its threat is mainly due to high concentrations of Zinc, TDS and Total Kjeldahl Nitrogen (TKN). On the contrary the pollution threat from fresh leachate arises mainly form high BOD, COD and chloride levels. However the threat exists from leachates from both fresh waste and aged leachate.
6.

\section{CONCLUSIONS}

1. Based on the physico-chemcial analysis the leachate from the active part (fresh waste) of the landfill, it has been inferred that anaerobic acidic phase is established.

2. The leachate from the closed part showed typical characteristics of leachates generated during the methanogenic phase of the landfill life phase.

3. Based on $\mathrm{BOD}_{5} / \mathrm{COD}$ ratio suggested that the leachate (sample-1) (closed part of landfill) from the landfill with the age more than 10 years and (sample-2) leachate (fresh waste) found to be in medium age.

4. The LPI is a quantitative tool by which the leachate pollution data of the landfill sites can be reported uniformly. High LPI values indicate that the leachates generated from landfill site are not yet stabilized even after 10 years, resulting in high pollution threat. While pollution threat from Leachate 1 (from old waste) is less from BOD and COD, its threat is mainly due to high concentrations of Zinc, TDS and TKN. On the contrary the pollution threat from fresh leachate arises mainly form high BOD, COD and chloride levels.

\section{REFERENCES}

1) APHA (1998), Standard Methods for Examination of Water and Waste water, 19th edition, American Public Health Association, Washington, DC. Brock T.D. and Madigan M.T.Biology of Microorganisms. 5th edition.Prentice Hall International inc 641 - 644.

2) Armstrong, M.D., and Rowe,R.K, (2009): Effect of landfill operations on the quality of municipal solid waste leacahte, In international Waste Management and Landfill Symposium, proc. Sardinia99, S Margherita di pula, Cagliari, Italy,.81-88.

3) Barlaz, M.A., Ham, R.K., and Shaefer, D.M. (2012): Methane Production form Municipal Refuse: A review of Enhancement Techniques and Microbial Dynamics,CRC Crit. Rev. Environ. Contr,19, 6,557.

4) Chain.E.S.K and Dewalle.E.B (1976), Sanitary landfill leachate and their treatment, Journal of Environmental Engineering Division, ASCE, 108(EE2), 411.

5) Granet.C, Courant.N, Millot. N, Rousseau and Navarro. N (1986), Diagnostic detrailabilite dex lixivials: definition d'une methodologie,L'Eau et l' Industrie. Janvier.

6) Harmsen.J, (1983), Identification of organic compounds in leachate from a waste tip, Journal of Water Research, 17(6), 699-705.

7) Hui, T.S. (2005), Leachate Treatment by Floating Plants in Constructed Wetland Master's Thesis,Universiti Teknologi Malaysia, Malaysia.

8) Kjeldsen, P., Barlaz, M.A.,Rooker, A.P., Balun, A., Ledin, A and Christen, T.H.(2002): Present and long-term composition of MSW landfill leachate: a review,criti Rev Environ Sci Technol,32:297-336.

9) Kumar, D., and Alappat, B.J (2003). A technique to quantify 
landfill leachate pollution, Proc., 9th Int. Landfill Symp. 243-244.

10) Peter .K, Morton A. B, Alix P. R, Anders B, Anna. L, and Thomas H.C,(2002), Present and Long-Term Composition of MSW Landfill Leachate: A Review, Critical Reviews in Environmental Science and Technology, 32(4), 297-336

11) Renou,S J.G. Givaudan, S. Poulain, F. Dirassouyan and Moulin.P, (2008), Landfill leachate treatment: Review and opportunity, Journal of Hazardous Materials, 150, 468-493.

12) Robinson,H.D \& Gronow. J.R.(1993), A review of landfill leachate composition in the UK, Proc. Sardinia 1, CISA, 821-83.
13) ZgajnarGotvajnA,Ti`slerTandZagorc-Kon`canJ(2009),Comp arisonofdifferenttreatmentstrategiesforindustriallandfillleacha te.JHazardMater162:1446-1456. 